УДК: 811.163.41-26

81’36:929 Белић А.

DOI: 10.18485/belic_slv.2016.1.ch1

\title{
Живојин Станојчић
}

\section{АЛЕКСАНДАР БЕЛИЋ И НАШ КЬИЖЕВНИ ЈЕЗИК - ГРАМАТИЧКО МИШЉЕЮЕ АЛЕКСАНДРА БЕЛИЋА}

Александар Белић рођен је 2. августа 1876. године у Београду. Ту је завршио средњу школу и започео, на тадашњој Великој школи, код свога професора Љубомира Стојановића (1860-1929), студије филолошких наука. Описујући његову изузетну даровитост и смисао за многе науке, и егзактне и друштвене, за уметност и литературу, његов ученик и, касније, његов сарадник и следбеник његових идеја у науци о језику, академик проф. Михаило Стевановић истиче: „Срећом за ову науку, нашу и општу, Белић се као главној струци посветио проучавању језика" (Наш језик Х, 3-6, Београд 1960, стр. 70). Вођен својим изузетним талентом, Александар Белић је као млад студент филологије и разумео потребе наше језичке науке тога доба, и оценио научне изворе који су му највише могли пружити. Тако М. Стевановић пише да је Александар Белић своје језичке студије обогатио у тадашњим двема најјачим лингвистичким школама: руској, код Ф. Ф. Фортунатова (и касније А. А. Шахматова), и немачкој, чији су представници били А. Лескин, К. Бругман и Х. Паул. Са научним основама тамо стеченим, Александар Белић је започео свој научни рад крајем XIX века (1897), да би од самог почетка XX века, од 1899. године, прво као наставник Велике школе, а онда као професор Универзитета у Београду (од 1905. године), члан Српске академије наука и уметности (од 1905) и многих других наших и страних академија, пуне 63 године, са прекидима у тешким временима I и II светског рата, како то бележи проф. М. Стевановић, радио на језичкој науци, обогативши ту науку и нашу културу са више од 600 књига, расправа и приказа. Таква његова плодност, када се оцењује у светлу његове делатности, научно-наставне на Универзитету, научне у Академији и тако свестране у друштву, посебно у епоси социјалистичког друштва, после победе наше револуције 1941-1945, као основе друштвеног напретка у историјским димензијама, 
у целости је доказала животност Белићевог схватања које је проф. М. Стевановић изразио речима да Александар Белић научни рад никада није делио од наставног рада, јер за „научни рад уопште треба прво формирати научне раднике, а то се по његовим схватањима... могло постићи прво наставом, дакако наставом истински универзитетског ранга, на факултетима, а универзитетска настава опет без научног рада не може бити оно што она треба да буде и што је Белић од ње увек тражио" (Наш језик, н. с., Х, 3-6, Београд 1960, стр. 72).

Дело Александра Белића, како то његови проучаваоци истичу, таквог је обима да се у великој мери поклапа са развитком науке о језицима Јужних Словена. Професор Миливој Павловић, један од тих проучавалаца, утврђује, тако, да је проучавање нашега језика добило прве смернице радом Ђуре Даничића (1825-1882), а затим Ватрослава Јагића (1838-1923), али наглашава и то да је XX век, и то пуних његових шездесет година, обележен управо Белићевим радом. „Са великом радљивошћу, са смислом за посматрање конкретних чињеница и за анализу и интерпретацију проучаваних појава, а у исто време синтетичног духа” - каже М. Павловић - „проф. Белић је свом обимном раду давао јединство циља, јединство методолошког смера и јединство погледа на научну проблематику" (Јужнословенски филолог XXIV, Београд 19591960, стр. 1). А то су чиниоци који су обележја модерне науке уопште, па тиме и обележја науке о језику како је данас узимамо. Када се овоме дода и еволутивност Белићевих погледа, и њихова стварна еволуција, која се може пратити кроз сва три видљива, али непрекинута, периода његове делатности од 1897. до 1960. године, када се његова делатност неминовном смрћу угасила, без и једне ограде може се рећи да је управо Белићева лингв ист ика била она жижа у којој су се преламале модерна европска и модерна наша наука о језику. То се може, дакле, рећи и за период Белићевих упореднограматичких интересовања, када интензивно и успешно обрађује посебна питања из славистике (1897-1904), која су и касније, у другом и трећем периоду, била изванредно поуздана основа његових обимнијих радова из упоредног проучавања словенских језика и његових општејезичких теорија, и за период његових дијалекатско-историјских испитивања српскохрватског језика (1905-1935), и унајвећој мери, рекли бисмо, за период његовог рада на питањима књижевног језика српскохрватског и на питањима теорије језика (1923-1960). Тада се, наиме, као резултат Белићевог огромног труда појављују не само његова капитална дела из појединих области, каквих је било у његовом раду и раније, него се на темељима модерне науке о језику, усавршавају и принципи на којима је заснован наш књижевни језик, и усавршава се 
сам тај језик, који се усмерава, и Белићевим радом, и радом других, у правцу веће правилности.

Целокупна Белићева делатност, и историјскојезичка, и дијалектолошка, и општелингвистичка, била је таква да му је и у области која је од највеће практичне важности за савремено друштво, за савремено општење међу члановима тога друштва, дакле, у области изградње књижевног језика као основног средства културног општења међу људима, - омогућила остварење општег лингвистичког метода. А у њему Белић је полазио како „од општејезичких принципа... тако и „од анализе свог врло утанчаног језичког осећања српскохрватског језика” (М. Павловић, Јужнословенски филолог XXIV, Београд 1959-1960, стр. 12), дакле, од оног што јепојединачно, посебно српскохрватско у оквирима општих језичких законитости.

Материја којој је Александар Белић откривао и изражавао правила била је управо та област. То јест - српскохрватски књижевни језик, који је уза сву своју природну разноврсност, што проистиче из Вуковог начела народне основе књижевног језика и из традиције сваког од културних центара - ипак основан на утврђеним фонетским (ортоепским и ортографским), морфолошким и синтаксичким правилима, на ономе што називамо јез ичком нормом. Зато је свака од језичких области те норме имала одговарајуће Белићеве радове: фонетика књижевног језика захтевала је Белићеве богате радове на образложењу принципа правописа и саме правописе, чији је он творац или учесник у изради; морфологија је дала и правописе, и граматике и правописне речнике; синтакса - не само граматике и студије о синтаксичким питањима, него и студије стила, Вуковог стила и стила писаца послевуковског времена. А целокупна норма захтевала је, и дала као богат плод, Белићеве лексиколошке радове, радове о развитку нашег књижевног језика и Белићеву богату делатност у вођењу и усмеравању лингвистичких часописа и других таквих публикација, посебно оних чији је задатак био неговање језичке културе. Као представнике Белићевог рада са тим циљем можемо навести књиге, студије и расправе као што су: Правопис (1923, 1930, 1934, 1950), Кюижевни језик српскохрватски (1927), Граматика српскохрватског језика I, II, III (1932, 1933), Вук и Даничић (1947), Око нашег кюижевног језика (1951), као и врло рано у раду на нормирању књижевног језика - низ програмских чланака Српскохрватски књижевни језик у часопису Наш језик, којега је био уредник од 1932. до 1960. године. У томе домену је и Белићево учешће у изради последњег заједничког правописа Матице српске и Матице хрватске (1960) и још много другог што садржи његова пребогата библиографија (в. Јужнословенски филолог XXIV, Београд 1959-1960, стр. 49-84). 
У своме Осврту на Белићево учење о језику, проф. Михаило Стевановић истиче да је Белић „у своме раду на испитивању језика увек имао на уму целокупност језичких факата, све врсте језичких појава, све елементе језика, свеукупност те најверније слике материјалног света у коме човек живи и најуниверзалније манифестације човекова духа" (Јужнословенски филолог XXIV, Београд 1959-1960, стр. 16). Можемо рећи да се овакав Белићев приступ, који се, природно, показао најупечатљивије у његовом делу О језичкој природи и језичком развитку I-II (1941-1959), јасно и доследно исказивао у решењима која је он пружао било у теоријским одређивањима књижевног језика, било у практичним упутствима која су, заједно са радом других посленика на језичком пољу - књижевника, граматичара, наставника и других, стварала наш књижевни језик и његову норму. Оно што се из практичних његових радова, из проучавања историје нашег савременог књижевног језика од његовог почетка, тј. од 1818. године, и из његових проучавања стила наших писаца, од Вука до Андрића, у погледу књижевног језика кристалише, Александар Белић је сажето и сигурно изложио и онда када је, проучавајући књижевни језик уопште, повезао настанак таквога језика и његове граматичке структуре са културним мишљењем, под чиме он разуме „мишљење у вези са предметима опште цивилизације”. И за то налази потврду управо у стварању српскохрватског књижевног језика, и то од његовог самог почетка, када је реч о модерном нашем књижевном језику - од Вука Караџића. Наглашавајући да се Вук трудио да језик његових дела буде чист народни језик, Александар Белић указује и на главни фактор који тај језик чини књижевним. Тај језик је књижевни - каже А. Белић - „по томе што се њиме обрађују књижевни предмети, што је он представник културног мишљења... Ако су мисли културне, и најпростији се језик претвара у књижевни. Значај књижевног језика није у језику, већ у мислима" (О книжевним језицима, Јужнословенски филолог XIX, 1-4, Београд 1951-1952, стр. 3, 5). А затим, у истој расправи, указује да је таквим књижевним језиком, основаним на народном језику, Вук обрађивао предмете из најразличитијих области: географије, етнографије, језика, историје, дакле - из свега онога што се назива цивилизацијом. И још више, подробније од тога - каже Александар Белић: „У другој половини XIX века... кроз књижевнике наш народни језик великог дела наше народне територије - ушао је дефинитивно у књижевни језик... Створиле су се, творачком снагом и наших књижевника, и научника, и стручњака и свих оних који имају непосредне везе са културним животом (политичара, публициста, уопште сарадника и учесника у повременим издањима и сл.) -... могућности за даљи слободни развитак нашег књижевног језика" (Јужнословенски филолог XX, 1-4, Београд 1951-1952, стр. 6). 
Очигледно је да је тиме Белић указао на потребу да се схвате могућности књижевног језика, оне, дакле, могућности које доносе промене. А својим непрекидним радом на неговању књижевног језика Александар Белић је очигледно указао и на то да те промене, тако природне у целокупном развитку језичком, треба да буду засноване на правилима која проистичу из састава, или, како се то обично каже - из природе српскохрватског језика, на коју је он у многобројним својим радовима указивао и коју је он, са тако великим успехом, непрекидно проучавао.

1. Два су чиниоца у стварању свакога књижевног језика и, у њему, и правописа: онај који зовемо језичким (лингвистичким) чиниоцем и онај који зовемо екстралингвистичким. И један и други познати су нам, а овде је реч о првом, који ми називамо још и граматичким м ишљењем, и уопште, а посебно онда када је у питању стваралац - говорни субјекат, књижевник, писац, беседник, граматичар. А граматичар Александар Белић као битне је уочавао следеће елементе Вуковог приступа ортографији новог српскохрватског књижевног језика: прво, Вуков правопис је обележавао само оне гласове који су се заиста изговарали; друго, Вуков правопис био је систем који је оперисао у принципу фонолошки/морфофонолошки, јер када су у питању језичке секвенце категорије реч Вуков правопис обележавао је „и изговор речи књижевног језика и све гласовне измене у юима"; треће, Вуков правопис био је систем знакова основан на индивидуалном изговору човека од кога је почињао нови књижевни језик са народном базом (в. стр. 129, 130 расправе А. Белића, О савременом правопису српскохрватског книжевног језика, Просветни гласник /Београд/ XL, 3 и 4, стр. 129-137 /I/, 206-221 / II/ и /III-IX/ - који се овде цитирају према посебном отиску из ПГл XL, св. 3-5, Београд 1923, стр. 1-40).

Ово последње, по А. Белићу, заправо је конкретан историјски елеменат, који се може утврдити датумом у развитку сваког књижевног језика, те као такав, рећи ћемо, остаје у сваком од њих као екстралингвистички потенцијал чије овакво или онакво остваривање, или овакав или онакав развитак, зависи потпуно од воље генерација које долазе после њега (исп. стр. 129 ПГл XL, 3, 1923). Тако бисмо данас интерпретирали уводне речи Белићеве програмске расправе из 1923, у којој он, излажући начела свога Правописа из те године, каже: „Када је Вук Караџић уводио народни језик у књижевност, када је, управо од њега 
отпочињао народни књижевни језик, он је као разуман човек морао поћи од себе и свога поколења и дати у правопису изговор речи свога времена. Тако је било некада и у другим књижевним језицима.” А пре тога, али по логичном редоследу после - „...старе књижевности, са великом прошлошћу и књижевним традицијама, имају историјске или, како се обично мало нетачно вели, етимолошке правописе. Оне задржавају правопис једног времена свога развитка као непроменљив, као стални, и онда када се језик већ знатно измени, тако да се обично ствара велики јаз између изговора и правописа. Тај је размак каткада веома осетан [...] тако да правопис, обележавајући симболички изговор, претставља, управо, везу са изговором предака, са старијим епохама књижевног језика" (ПГл $\mathrm{XL}, 3,1923,129)$. А дата интерпретација стоји утолико пре што је читав Белићев напор у овој области књижевнојезичке кодификације управо усмерен на очување морфофонолошког принципа у српскохрватском правопису.

Наиме, прво питање које А. Белић поставља у своме програмском чланку гласи: „да ли се неће и Караџићев правопис претворити у историјски, ако се за сва времена задржи све онако како је Вук предложио, ако се измена његова правописа не изврши и онда када се од њега изговор удаљи?” И први, логични наравно, одговор његов: „То ће свакако бити, ако се будемо држали спољашњих знакова Вукова правописа, а не унутрашњих, форме, а не садржине" (ПГл XL, 3, 1923, 130).

2. Као природна консеквенца ове Белићеве бојазни, с једне стране, и Белићеве фонолошке/морфолошке оријентације, с друге стране, које су уочљиве у констатацији да је, неким Вуковим колебањима и неким недијалектичким поступцима каснијих генерација граматичара, „створена опасност да наш правопис изгуби своје особине: своју фонетичност и своју правилност" (ПГл XL, 3, 1923, 131) - израсла је методологија ове његове, како смо већ истакли, програмске расправе. Отуда је Александар Белић у њој истакао најпре двоје:

(1) Прво - „да се наш књижевни правопис оснива пре свега на изговору. Оно што се у засебним речима изговара, мора бити дато на писму. То је суверени принцип нашег правописа. Наравно, [...] онолико колико општа средства наше азбуке то допуштају; у гласовне преливе код појединих гласова, у модификације извесних особина гласова које још не мењају њихову основну природу ${ }^{1}$ - ниједан се правопис не упушта" (ПГл $\mathrm{XL}, 3,1923,130)$.

\footnotetext{
${ }^{1}$ А. Белић овде мисли на позиционе варијанте фонема, нпр., нос : Анка.
} 
(2) Друго - да је, предлажући свој правопис сам спреман да ортографски поступак усмерава тако да најбоље одговара „духу нашег правописа и духу нашег народног и књижевног језика”, имајући, како каже, „на уму не само основне принципе Вукова правописа, него и начин на који је он те принципе применио" (ПГл XL, 3, 1923, 132).

При томе, Александар Белић ће доследност садржају (1) релативизирати садржајем (2), јер ће под начином на који је Вук дате принципе применио он схватити, и узети у обзир, и случајеве Вуковог колебаюа: „Вук Караџић је показао велике духовне способности када је извршио примену свог фонетског правописа на целом материјалу нашег језика. Али се и он могао по негде колебати [...] То колебање[...] код њега се може разумети" (ПГл XL, 3, 1923, 130). Овај став Александра Белића сасвим је јасан из једноставне констатације коју даје: „Кад говорим о духу нашег правописа, ја имам на уму не само основне принципе Вукова правописа, него и начин на који је он те принципе применио" (ПГл XL, 3, 1923, 132).

3. Отуда Александар Белић у својој програмској расправи 1923. године, предлажући нормативна решења, свакој од спорних категорија прилази и категоријски и појединачно, другим речима, са морфофонолошког гледишта и лингвистички у највећем степену. А степен спорности тражене појаве, одн. интензитет тешкоћа које условљава у решавању основног односа говорни језик : писани језик, за А. Белића је и критеријум редоследа и он те категорије види овако:

(A) Категорија изговор/писање фонеме j: ,једна је однајтежих и можда, највише вештачки изведених особина нашега правописа" (ПГл XL, $3,1923,132)$. По А. Белићу, артикулационо фонема је двојака: (а) потпуно или јако $~$ и (б) непотпуно или слабо $j$. Он их позиционо-фонетски одређује:

(а) „свако $ј$ које се находи између самогласника од којих ниједан није u - јесте јако j" /oja, yja, eja, ajo, ajy, yje, yjy, еjy, еjo.../, ПГл XL, 3, 1923, 132;

(b) „свако $ј$ које се находи између самогласника од којих је бар један u јесте слабо j” / uja, uju, yju, ujo, aju, ијy, оји.../, ПГл XL, 3, 1923, 132.

А ова се ситуација, уочава А. Белић, наравно другим речима, компликује тиме што је секвенца типа $i+j+V^{*}$, одн. $V+i$ заправо једнака секвенци $i+V$, односно $V+j+i$, тј. потпуно су једнаки, по А. Белићу, у нашем књижевном изговору скупови: $u a=u j a ; u o=u j o ; a u=a j u ; e u=e j u ; y u$

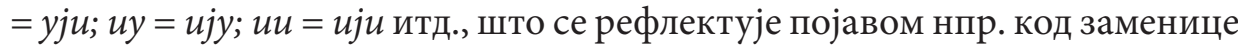
мој:

$$
\mathrm{V}=\text { vokal }
$$


(a) јаког ј: мој, моја, моје, моју...

(b) слабог ј: моји, мојим, мојих, мојима...,

тј. фонетски различитог $j$ у идентичној категорији (морфемски ниво парадигме) и, обрнуто, идентичног $j$, слабог или јаког, у различитим категоријама.

4. А. Белић, „на основу његова начина писања, његова језичког материјала”, изводи Вуков принцип:

(a) јако или потпуно ј Вук увек и без колебања пише /jaje, nepaja, чароје, мој, твоја итд./;

(b) слабо или непотпуно $\mathrm{j}$ Вук условљава категоријом, тј. разликује према категорији и види два $j$ :

$\left(\mathrm{bb}_{1}\right)$ у наставцима за облик или за образовање речи, одн. у етимолошким облицима, када га и бележи знаком $j$ : мојих, бијем, забијати, пријатељ : пријати, појити, дојити, перајица : пераја; освојити : својој итд. и

$\left(\mathrm{bb}_{2}\right)$ у позиционим остварењима, када се $ј$ развијало у додиру два вокала од којих је један $u$, када га бележи ознаком ø, тј., како А. Белић каже, „пропуштањем”, дакле, рекли бисмо, у неграматичким категоријама, где „по пореклу није оправдано”: иоле, прионути, приағати, наимати, заимати, одн. у неким граматичким категоријама, где такође по пореклу није оправдано: носио, био, возио итд.

А. Белић налази да је Вуково решење овде недоследно фонетском принципу, али да је принцип који је видљив у њему ипак јасно одређен (граматичка категорија : неграматичка категорија), те да га не треба мењати, него доследно спровести:

- обележавањем слабог $ј$ знаком када се оно налази испред наставака за облик или наставака за творбу речи (Илијин од Илија);

- испуштањем слабог $ј$ када се оно налази у речима које су примљене у наш језик са готовим страним секвенцама типа слога -иa, -au, -оu и сл., тј. речима у којима се даље извођење не врши домаћим средствима (каиш, даире, чиода, материал, библиотека, диамант, националан, диалект, материалан и сл.).

Доследност коју предлаже, А. Белић повезује с Вуковим решењем: у случајевима овога типа секвенце -io-, -ai- једнаке су са Вуковим етимолошким -іо- (иоле, водио, диоба и сл.), а -ija-, -ije- (начија, геније и сл.) једнако је са Вуковим -ija-, -ije-, у којима је $j$ по пореклу свом у нашем језику оправдано" (ПГл XL, 3, 1923, 134). Наравно, овде А. Белић скреће 
пажњу на потребу да се води рачуна о тачности етимологије. Нпр., каже он, - „у нација имамо ја које врши функцију у нашем језику” (ПГл XL, 3, 1923, 134), дакле - узима да је $j$ део морфеме са функцијом давања српскохрватског облика страној речи, те да се етимолошки оправдава, док смо секвенцу са такође слабим $j$ које се испушта у писању у националан добили у истом облику из страног језика. Отуда код њега односи: специалан а специја; материал и материалан а материја и сл.

5. У овој категорији за А. Белића одвојено питање представља секвенца $V+j+K^{* *}$, одн. $V+j$, тј. гласовни скупови у којима се фонема $j$ налази пред сугласником одн. на крају речи. Констатујући ортографски обичај изражен примерима: шумадијски, аустријски, пиј, бијмо, судијски, убијство...// иумадиски, пи, бисмо, судиски, убиство..., А. Белић поставља питање: који од та два начина треба и даље задржати (ПГл XL, 3, 1923, 134). Он експлиците одговара да то зависи од тога „како се такво иј изговара”, а да се по њему „ту чује само $u$ дуго, без икаквог сугласника j” (ПГл XL, 3, $1923,135)$, што потврђују и каснији испитивачи. ${ }^{2}$ И то - после полемике са Новаковићевим схватањем доследности принципу очувања облика и после „полемике” са Вуковом и Даничићевом праксом, који пишу убиство и убијство, аустриски и аустријски, Шумадијнаи, Шумадијнка, иумадијнски u Шумадинаи итд., са несумњиво лингвистичком аргументацијом и са гледишта синхроничке морфофонологије (исп.: „Питање је да ли је гај : гајски или Баја : бајски заиста знак органске системе код придева на -ски или знак гласовне неопходности. Ако погледамо остале придеве као: луг : лушки; Млеци: млетачки; роб : ропски; Влах: влашки; девојка: девојачки; лупеж : лупешки итд., видећемо да у нашем језику нема тенденције да се код придева са наст. -ски задржава гласовни облик речи од које се придев изводи, већ се у сваком појединачном случају врше измене које су у духу нашег језичког развитка. Зато нема разлога стварати вештачки неку 'доследност' које у самом језику нема”, ПГл XL, 3, 1923, 137) - предлаже да се усвоје облици без $ј$ тј. тип: щумадиски, бимо, судиски, убиство, пи пимо. Тиме би правопис, мисли А. Белић био „ослобођен још од двеју неправилности које нимало не увећавају ни његову јасност ни изразитост" (ПГл XL, 3, 1923, 137).

\footnotetext{
** $\mathrm{K}=$ konsonant

2 В.М. Стевановић, Језику Вуковуделу и савремени српскохрватски књижевни језик, Јужнословенски филолог XXVI, 1-2, Београд 1963-1964, 78; П. Ивић, Поговор Вуковом Рјечнику 1818, Просвета, Београд 1966, 114-115.
} 
6. (В) Категорија изговор / писање $\partial c / m c$ : „једна је од најкрупнијих или за консервативне људе најосетнијих новина коју ја предлажем - да се Караџићево дс замени групом $m c$, која једино одговара систему гласовних промена нашег језика и систему гласовних бележења нашег правописа" (ПГл XL, 3, 1923, 206). А представља бриљантну лингвистичку тезу, изведену мајсторском аргументацијом, која је достојна Белићеве лингвистичке мисли. Који су правци Белићевог морфофонолошког размишљања?

Прво, А. Белић узима као правилну Вукову констатацију односа који се уочава у стању:

(a) у изведеним речима / у облицима: $\partial / m c>u_{,}$одн. $\partial / m u_{s}>u_{\text {s }} /$ ль $u_{\zeta} \kappa u$, одн. оца/;

(b) у сложеним речима: $\partial / m c>m c$, oдн. $\partial / m u_{s}>m u /$ nотсирити, одн. отиурити/,

- констатацију коју он дефинише: „Караџић је констатовао, судећи по примерима које он наводи и по ономе што он о њима говори, две ствари: a) да се код изведених речи на ски и ство $\partial$ и $m$ испред тих наставака обично изговарају или као $u$ или да их у изговору и сасвим нестаје, на пр. госпоцки : госпоство и сл.; и б) да се код сложених речи са предметком који се завршује сугласником д обично изговара $\partial$ или $m$, на пр. подсирuти, одсвакле, одслужити итд. Видећи тако различите изговоре, Караџић je, иако признаје да би било најправилније писати $m c$, оставио 'онако', тј. оставио по етимологији, на пр. братски, градски, господство, подсирити и сл." (ПГл XL, 3, 1923, 207).

7. Друго, признајући правилност Вукове констатације, А. Белић му оспорава правилност закључка и указује на два начина којима је Вук могао и остати веран фонетском принципу и регулисати ортографску тешкоћу која је у питању. По А. Белићу, Вуково решење требало је овако да се развије:

(а) тип наставачке секвенце -дски, -тски, одн. -дство, -тство, с обзиром на утврђени изговор -изки, одн. -ство, могао се обележавати доследно фонетски тј. са - ; $_{\text {; }}$

(b) тип префиксалне секвенце, зато што у српскохрватском језику има више случајева да су „гласовне прилике код предметака нешто друкчије него код сугласника у речима изведеним наставцима; јер се предмеци [...] осећају као засебни делови речи, са значењем које они уносе у сложене речи" (ПГл XL, 3, 1923, 208), могао се обележавати са извршеном фонетском променом / подсирити > потсирити / која се чува у тим оквирима, 
без даљег развитка $/ m c>$ u/, управо зато што је у језичкој свести присутан и елеменат „психолошки процес сталног подмлађивања предметака", тј. процес: подсирити > ${ }^{\star}$ поцирити > /подсирити/ > потсирити, у којем * облик, који је фонетски остварљив, морфофонолошки нема услова за постојање, јер га језичка свест враћа на облик са $-m c$, у којем се садржи слика -дс- из везе префикс + осн. реч /под + сирити. Овакав поступак апсолутно би био идентичан са оним који Вук примењује, доследно фонетски, или боље рећи - морфофонолошки, у типу: откуцати, поткивати, поткупити, искривити, наткрилити итд., где је у језичкој представи, како А. Белић тачно уочава, увек од-, под-, из-, над- итд., дакле - са гласовног гледишта - остварење одговарајуће фонолошке опозиције (т/д, с/з итд.).

8. Александар Белић уочава лингвистичке разлоге Вуковог компромиса у бележењу секвенци типа (а) и типа (б). Наиме, секвенце типа *брацки // братски // браски; грацки // гратски // граски (одн. потсирити // посирити // поцирити) с једне стране, а психолошка представа фонеме $\partial$ из сложених секвенци типа подсирити, која се видела у фонетском остварењу потсирити управо због различитости „гласовних прилика код предметака" у српскохрватском језику уопште, с друге стране, натерала је Вука „да одреди исти начин обележавања групе дс у свима положајима" (ПГл XL, 3, 1923, 211). Овај компромис, међутим, сместио је Вуково решење у област е ти молошког правописа и створио могућност да се касније отворе и широм врата етимологији у писању. О томе сведочи, уз констатовање, и Белићева полемика са Ст. Новаковићем, одн. о „насилном” успостављању писаних облика типа: одиити, жеди, почетци, подчинити, судии, одиурити итд. (ПГл XL, 3, 1923, 212-218). Али да је А. Белић, уз све своје разлоге, и сам увидео да су извесни компромиси и неминовни и оправдани, доказ је његово прихватање Вуковог принципа с писањем $\partial$ испред два наставка (-ски, -ство) у Правопису од 1930. и Правопису од 1950 (в. и т. 24).

9. Треће, примајући принципијелни део Вуковог решења, „Караџићев начин на половину, донде докле је он правилан”, А. Белић на основу детаљне аргументације, која садржи и синхронички (ПГл XL, 4, 1923, 208-209) и дијахронички део (ПГл XL, 4, 1923, 208-211), долази до свога предлога - „у духу Караџићева, фонетичког правописа: да се свугде где он пише $\partial c$ - пише доследно $m c$, онако како се та гласовна група обично у нашем језику изговара, дакле: потсиритu, отсећu, omсвагда, гратски, војвотство и сл., исто онако као братски, братство итд." (ПГл XL, $4,1923,211)$. При томе, несумњиво најзначајнији део овог 
кон кре тног Белићевог предлога сигурно је, уз дијалектичку могућност ограничених компромиса коју А. Белић оставља тиме што уводи принцип п о с т уп н ост и, ${ }^{3}$ у његовом доследно морфофонолошком принципу. „Психолошки је принцип”, каже А. Белић, „нашег правописа - да се оно пише што је у изговору, у претстави слуха. Када се пак полази од онога што је написано, дакле од претставе вида, и према њој одређује однос у изговору - онда се и психолошки и физиолошки наш правопис ставља на основицу историских правописа. А када се у извесном броју случајева правописне особине ставе на ово земљиште, онда више не помажу никаква ограничавања. Јер и само полусвесно извршена апстракција онога што се садржи у поменутим насилним аномалијама, довољна је да помути право осећање за фонетички правопис, који се, у целини и пуној доследности, може одржати само онда кад представља систему гласова заиста основану на изговору. Чим се тај однос поремети, системе више нема, и нема више могућности да се правопис заснује на осећању реалних разлика у изговору гласова" (ПГл XL, 4, 1923, 216). Условљеност кон кре тног решења и другим, а не само граматичким чиниоцима, наравно, пружала је могућност (а и сам факат) и других решења (в. т. 24).

10. (С) Категорија изговор / писање фонеме х.- Истицање овога питања које чини А. Белић у своме програмском чланку, тада, 1923. године, могло је имати само практичан значај. У принципијелнотеоријском смислу ситуација је била сасвим јасна, и она се не би ни данас могла боље дефинисати. Глас $x$ Вук Ст. Караџић „уводи иако га није било у његовом матерњем говору, зато што га је налазио у другим народним диалектима (дубровачком, бокељском источном црногорском ${ }^{4}$ итд.)”, другим речима, зато што је, како каже А. Белић, тада (1836) „пред његовим очима стајао нов идеал: идеал једнога, заједничког књижевног језика”, ...а „тај нас је глас спајао и са архаичнијим (чакавским и кајкавским) говорима" (ПГл $\mathrm{XL}, 4,1923,219)$. Како бисмо данас рекли, $x$ је знатно проширило основицу књижевног језика у погледу територије, уједначило језик у погледу

3 „Сем овог компромисног, помирљивог начина [...] могао би бити само још један [...] Могло би се за изговором ићи докраја и бележити оно што се у ком случају најчешће јавља: а) код предметка - $m c$; б) код наставка -cкu, -ияки и в) код наст. -ство - ство. Ја нисам сматрао да у овом правцу треба ићи докраја, а кад се и у самом кюижевном језику изврши измена т пред ски и ство докраја, тада се и овај последњи део развитка ових гласова може примити онако како се он изврши” (ПГл XL, 4, Београд 1923, 212; в. и стр. 217-218).

4 Посреди је омашка - треба да стоји староцрногорском. 
обличког система (нпр., орах, орах-а м. ора, ора-a; плетаху м. плетау; добрих м. добри итд.) и усавршило континуитет у историјском смислу (в. П. Ивић, Поговор Вуковом Рјечнику из 1818, Београд 1966, 108, $110-$ 111). А ово последње, усавршавање континуитета у историјском смислу, с обзиром на функције и задатке књижевног језика у комуницирању у временској пројекцији једне стабилне друштвено-језичке заједнице, није од најмањег значаја.

Природно, и овде Александар Белић стоји чврсто на становишту фонетичности правописа, с тим што је дијалектички схвата: ако се $x$ не налази у систему Вукове језичке основице, ширењем основице други делови народног говора, а рекли бисмо и литерарних творевина на њиховим основицама, тај глас уносе у савремени књижевни језик. А проблем могућности повратка етимолошког $x$ и решава исто тако дијалектички - компромисом: немогуће га је вратити у типу ${ }^{\star}$ hor $>^{*}$ thor $>$ tvor или trula (>truhla) : truo ( $>{ }^{*}$ truhao), али ће ce $x$ „задржати тамо где се језичко осећање савременог поколења против юега не буни сувише” (ПГл XL, 4, 1923, 220). Овај еластични принцип, који рачуна са квалитетом потенцијалног развитка у било којој фази (а који се од 1923. године до ових дана, дакле у полувековном развоју, изванредно потврдио), Александар Белић омеђује сигурним, чврстим ослонцем: $x$ ће се обележавати „према теоријским захтевима, т. ј. према оним диалектима нашим у којима се тај глас сачувао досада или према прошлости нашега језика, када још није било губљења овога гласа у нашем језику" (ПГл XL, 4, 1923, 221). Његов Правоп ис из 1923. године то и конкретизује одређивањем низа случајева у погледу књижевнојезичке прихватљивости: буздован м. буздохан; буха // бува; глувльи м. глуши; зехати // зевати; аждаја м. аждаха; осмех м. осмеј; ар м. ахар; хвалити м. фалити; банути м. бахнути итд., од којих, наравно, многи данас имају не ознаку м. (=место), већ ознаку // (=напоредо): кинути // кихнути; заманути // замахнути и сл., док би се за неке од њих могло оставити м., али обрнутог смера (нпр. код А. Белића: насменути се м. насмехнути се, данас ће сигурно бити обрнуто: насмехнути се м. насменути се и сл.). ${ }^{5}$ Различит конкретни развитак појединих лексема ниуколико не противуречи Белићевом тачно формулисаном принципу, у који је укључен и елеменат граматичаревог доприноса - попис свих случајева употребе тога гласа и одређивање његове стандардности на основу књижевне употребе гласа $\mathrm{x}$ „у добрих књижевника, који осећају сву величину задатка који је пред

${ }^{5}$ В.: А. Белић, Правопис српскохрватског књижевног језика, Београд 1923, 33-39; Правопис српскохрватског књижевног језика МС и МХ 1960 (Речник). 
њима, књижевника који осећају језик и владају духом његовим" (ПГл XL, $4,1923,220)$.

11. (D) Категорија писање вокала $e$ или $u$ код глагола типа белети / белити и сл. - представник је ширег проблема који ће А. Белић, узимајући у својој аргументацији потребу уједначења система како га и Rječnik JAZU даje (bijeleti / beleti neprel., "postajati beo”; bijeleti se / beleti se neprel. „бити бео” : bijeliti prel. лице, образ, платно / beliti „бојити бело”; bijeliti se / beliti se „mazati se bjelilom”), дефинисати као потребу за разрађеном граматиком савременог српскохрватског књижевног језика. У тај круг питања А. Белић сврстава и регулисање односа суфикса -атu, -ивати / -ујем и -авати / -авам у образовању глагола, када се појављују јотована и нејотована алтернација сугласника (писати - записивати : огласити - оглашавати, надвисити - надвишавати и др.), као и однос типа седене, летене - сѐђёюе, лѐће̄юе : седети, летети и сл. (О савременом правопису српскохрватског књижевног језика, прештампано из Просветног гласника XL, св. 3-5, Београд 1923, 26-29). ${ }^{6}$ А. Белић, наиме, такву граматику, која је творбени и синтаксички материјал савременог, поствуковског језика, научном анализом изложила у систему („довела у склад”), сматра условом и правописних упутстава.

12. Отуда је у првом Белићевом Правопису овим питањима дато доста места. Поглавље IV (О писању глагола са самогласником Е у једним облицима - нач. неодр., прећ. сврш., прош. прил. и прош. придеву - а у другим са И), дескриптивно-прескриптивним методом говори о граници између гл. на -ити и -ети садржећи конкретне парове (белети / белити и сл.; омилети / омилити и сл.; ослепети / ослепити и сл.; горети; летети; хитеmu; бежати - бежим и др. на стр. 22-27), док поглавље IX (Јотовање код извесних глагола на АТИ, АВАТИ, ИВАТИ), истим тим методом, говори о формирању стандарднојезичких типова извођења (исп.: јавити - јављати; допунити - допуюати, допуюавати, допуғивати; питати - запитивати; носити - донашати; крстити - укритати, крштавати; сванути свағивати; искати - иштем и др., на стр. 52-58), који су, у полувековном развитку од 1923. године до данас, сви апсолутно потврђени на најширем подручју српскохрватског књижевног језика, укључујући ту, наравно, не само језичку праксу, јер из ње они и излазе, него и формулисане језичке системе, дакле граматичку литературу с карактером нормативности.

${ }^{6}$ Пагинација у овој расправи одавде иде по сепарату истог Белићевог чланка прештампаног из ПГл XL, св. 3-5, 1923, Државна штампарија Београд 1923, стр. 1-40, а броју страница претходи наша ознака посебног отиска „п. о. ПГл XL, 3-5", са укљученом годином 1923, наравно. 
13. (Е) Категорија изговор / обележавање слога. - Уколико је у данашњем нашем правопису ова категорија добила чисто конвенционални карактер, тако да се то огледа и у наслову поглавља - Растављағе речи на крају слога (гл. XVI, Правопис МС-MX 1960, 130-131), утолико је Белићева интерпретација датога питања у чланку којим је он образлагао своја практична решења у Правопису из 1923. године била у сфери фонологије, или тачније - морфофонологије. Белићево размишљање овде, с обзиром на практичан циљ који је имао пред собом, иде у правцу прикупљања аргументације која ће показати ж и в ос т п р оце са , а то значи, са практичног гледишта - демонстрацију фонетског онда када се посматра однос говорни језик: писани језик. Томе је усмерен Белићев екскурс у развитак језика и констатација „да за поделу слогова не може бити сталних правила за сва времена и све језике, него да се према сваком времену и према сваком језику мора то утврдити према природи његовој” (п. о. ПГл XL, 3-5, 1923, 30).

14. Међутим, демонстрација фонетског, колико је формулише у односу пти-иза: лоп-та; пше-ница : леп-ше; где : сваг-да као у односу који се базира на дистинкцији почетак речи : средина речи, по А. Белићу се компликује и психолошком границом слога у односу какав имамо у типу: ис-ту-ћи : сва-сти-ка; из-ди-ћи : бра-зда; из-не-ти : кр-зно; нај-ода-ни-ји : ко-јој; из-у-мре-ти : ве-зу-јем. Као и у случајевима једначења (в. т. 7-8), А. Белић је види као манифестацију извесне самосталности „предметака или саставних делова речи које они имају у нашој свести. Наравно, потребно је да у томе делу речи заиста и одговара извесна претстава у нашој свести; јер чим тога нема, кад је реч сложена, а не осећа се као сложена, већ као проста, она се дели по гласовним правилима" (п.о. ПГл XL, 3-5, 1923, 31). Довољно је за ово навести етимолошке сложенице разум, отићи, отети, које А. Белић дели по фонетским

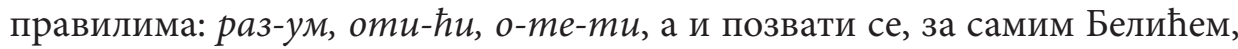
на поглавља XII, 3; XIII, 3; XIV, 2 и XV, 7 његовог Правописа из 1923. године. За ситуације средине речи, дакле - изван очигледних композиционих условљености, А. Белић утврђује чисто гласовно правило: „да се у слогу допушта само једна експлозија, само један прекид ваздушне струје" (ПГл XL, 3-5, 1923, 31), што, зависно од сугласника који учествује у додиру, и уз аксиом о понашању вокала, даје поделе типа: ла-ста, ри-зни-ияа, па-жна, бра-зда, ко-ска, гро-жђе..; мо-три-ти, чове-чји, ми-ильу...; свад-ба, воћ-ка, квоч-ка; леп-ши, флекс-си-ја, диг-нути...; кор-па, ов-са, кај-си-ја, зам-ка, валь-ка, ба-кал-ка, хую-ка-ти...(п. о. ПГл XL, 3-5, 1923, 31-32). 
15. (F) Категорија писање малог и великог слова и интерпункција.- У Белићевом првом правопису, ове категорије, релевантне за нормирање сваког писаног језика и, често по критеријуму спорности или јасноће у примени - међу сталним питањима језичке праксе, обухваћене су XVII и XIX поглављем, која дели само поглавље напомена о туђим речима (XVIII). Могло би се рећи, с обзиром на карактер XVIII поглавља (напомене!), да се ове категорије, као релевантне за принцип, настављају. А Белићево лингвистичко / граматичко мишљење, будући свесно сасвим тесне везе између писане и говорне норме у културно развијеној језичкој заједници која је створила писану норму, ${ }^{7}$ у овоме погледу не иде на случајна представљања, одн. решења. Чак ни у погледу редоследа. Критеријум везе ових двеју категорија је у Белићевом одређивању психолошке границе, у првом случају - речи као јединице одређене врсте, у другом - реченице, одн. њених делова, опет као јединица одређене врсте. Из овога проистиче и веза практичних правила са (синхроним) језичким осећањем, што - mutatis mutandi одговара односу писаног знака и фонетске стварности, који смо до ових двеју категорија разматрали, па и ономе делу те стварности који нужно претпоставља и стварност психолошких представа (в. т. 7-8, 14).

16. (а) У оквирима прве категорије, писања великих и малих слова, колико год да је то „ствар условна”, А. Белић у своме програмском чланку уводи психолошки састојак перцепције, предлажући две групе језичких секвенци. (1) У првој, коју чине имена предмета или лица, тј. све оно што је право име и перципира се, дакле, као нарочито издвојени појам - пише се почетним великим словом, а оно што је опште име - пише се малим словом. (2) У другој групи, коју чине секвенце, а Белић изванредно срећно каже „цитати и све оно што до извесне мере има тип цитата, утврђених, сталних карактеристика" (п. о. ПГл $\mathrm{XL}, 3-5,1923,33)$ - почетно слово само је велико, а „остале речи имају писмена која им по њиховој природи припадају”. Јасно је да прва група имплицира и однос обележен код А. Белића као Драконов - драконски, Ћирилов - ћирилски, док друга - у којој је психолошки елеменат изражен тежиштем, дакле, апсолутно психолошки - рекли бисмо, срећније него каснији правопис, ${ }^{8}$ оставља могућност Дубровачка улица : улица Дубровачка, јер је, како А. Белић каже, „овде тежиште у имену којим се одређује опште име." Наравно, као што је то увек у решавању задатака

7 Jiři Krámský, The World as a Linguistic Unit, Mouton The Hague - Paris 1969, 53.

${ }^{8}$ В.: Босанска улииа, Улица босанска и др. у Правопису МС - MX 1960, 19. 
ове врсте, конвенционални карактер правописа, који је једно од његових главних својстава у сваком језику, па и у српскохрватском, диктирао је сва појединачна решења. Посебно је то изражено онда када А. Белић уводи количински критеријум, који допушта однос типа Српска Кюижевна Задруга : Упутство за прибиране грађе за народни живот и обичаје, јер - „ако су ти називи већи од пет речи, пишу се само великим почетним писменом прве речи" (А. Белић, Правопис, Београд 1923, 116), и који у каснијем развитку српскохрватске књижевнојезичке ортографије, наравно, као конкретно решење није прихваћен (исп.: Правопис МС - MX 1960, 18-19). Уосталом, то је судбина и многих других конкретних решења у нормирању књижевних језика уопште, што никако не значи да сама по себи негирају језичке принципе .

17. (b) У оквирима друге категорије, интерпункције као правописног питања, у условима које проф. М. Стевановић, историјски и по себи, дефинише следећим речима: „она [правила интерпункције прим. Ж. Ст.] ће моћи да се изведу тек после претходно тачно утврђених принципа којима су се у примени интерпункције руководили најбољи стилисти и познаваоци језика", речима које подразумевају учешће интерпункције у целокупном комплексу некодифи ков ан ост и правописне материје на овој страни књижевнојезичког подручја до Александра Белића - Белићева лингвистичка / граматичка мисао има посебан значај. Такав значај има поготову онда када се стави у историјску перспективу, у одговарајући контекст, који показује да смо поред чињенице Вука Ст. Караџића и Ђуре Даничића са релативно завршеним логичким (= психолошким) системом од 1847-1850, Стојана Новаковића 1894, Српског књижевног гласника (1901), Политике (1904) и генерације књижевника после тог периода, све до Белићевих правописних активности, имали и чињеницу „одсуства сваког принципа у примени интерпункције” као дела кодификованог књижевнојезичког система. ${ }^{10}$

18. Управо је отуда необично важна прва констатација Белићева: интерпункција је, у ствари, део синтаксе (п. о. ПГл XL, 3-5, 1923, 33). Као таква, она је у Белићевом програмском чланку, одређена

- функционално, као систем ознака како шта треба разумети (п. о. ПГл XL, 3-5, 1923, 33); и

9 М. Стевановић, Вукова интерпункиија, Зборник Филозофског факултета, II, Београд 1952, 18.

10 В. М. Стевановић, Ibid., 19, 38-43. 
- садржински, као систем ознака врсте везе, одн. одсуства везе међу речима и реченицама,

при чему се, на зарезу као типичном за ову област симболу, указује на психолошку вредност с т в арн ог, а не фор ма лн ог односа међу језичким јединицама (конкретно - реченицама, а условно - речима). У Белићевом ограничењу да се „на уму има обична, психолошки правилна реченица”, која „нема никакве нарочите стилске обраде, којом би се реметила првобитна веза речи у реченици" (п. о. ПГл XL, 3-5, 1923, 35), наравно, присутан је моменат ограничења на нормалне комуникацијске околности, које укључују потребу кодификованог стандардног система синтаксе. За историјски контекст који је описао проф. М. Стевановић, дакле - до 20-их година овога века и у источном књижевнојезичком поднебљу, ${ }^{11}$ утврђивање овог де̂ла кодификоване норме, било програмски, што значи - теоријски (нпр., кад је реч о зарезу - да се заснива на опозицији одсуство непосредне узајамне зависности: присуство непосредне узајамне зависности и др.), ${ }^{12}$ било практично, правописним правилима, ${ }^{13}$ у тако завршеном виду по себи је значајно. А, при томе, представљало је почетак Белићевог непрестаног рада на истом сложеном питању, рада који је долазио у наредним деценијама и у којем је А. Белић стално био на становишту које је могао, 1949. године, формулисати као однос синтаксе и знака (симбола): „Не треба се бојати тога што се ова интерпункција назива синтаксичком и не треба мислити да то тражи од писца неких особитих граматичких знања која су им неприступачна без нарочитих, дубоких студија. Синтакса, тј. оно што се износи у нашем говору, - није ништа друго [...] до израз нашег мишљења. Све што је у мишљењу нашем повезано везама зависности, дакле најтешњим везама које се замислити могу, не може бити одвојено при писању, и обрнуто, све што је одвојено у мишљењу не може бити спојено при писању. То је главно или основно правило сваке разумне интерпункције. ${ }^{14}$

${ }^{11}$ М. Стевановић, Ibid., 19, 38: А. Белић, Наш правопис у новој обради, Наш језик н. с. VIII, 3-4, Београд 1956, 66-67.

12 А. Белић, О савременом правопису српскохрватског књижевног језика, прештампано из ПГл XL, 3-5, Београд 1923, 37-38.

13 А. Белић, Правопис српскохрватског књижевног језика, Београд 1923, 127-154.

${ }^{14}$ Наш језик н. с. I, 1-2, Београд 1949, 10 и д. В. и прилоге: Око језика и правоnиса, Наш језик н. с. IV, 3-4, Београд 1952, 79; Јединство новог правописа, Наш језик н. с. IX, 5-6, Београд 1958, 145-147; Наш нови правопис у новој обради, Наш језик н. с. VIII, 3-4, Београд 1956, 65-70. 
19. Значајан лингвистички садржај наведених Белићевих расправа, са конкретним дефинисањем односа мишљења и језичког знака у чланцима из 1923. и 1949 (в. стр. 33-38, одн. 7-23), које никако није могло бити исцрпено, као свој исто тако значајан потенцијал имао је екстралингвистичку страну питања, ако се под њом разуме двоје: даље ангажовање граматичке мисли и организовање чинилаца конвенционалног у изградњи правописа. На постојање и комплексност ове стране упућивао је пажњу настављач Белићеве мисли у кодификацији стандардног српскохрватског језика, професор Миха ило Стевановић пре свега исцрпном расправом Вукова интерпункција, ${ }^{15}$ у којој, излажући генезу наше логичке интерпункције (стр. 18, 38-43) и изводећи њена правила из Вуковог поступка заправо „експлицира” синтаксу. Он, даље, у расправи Измене у правопису српскохрватског језика, ${ }^{16}$ у којој, са комплексног екстралингвистичког гледишта, истиче значај слободне (синтаксичке) интерпункције и значај њеног кодификовања у заједничком правопису, у којем је у периоду 1954-1959. Александар Белић имао изузетно великог удела, - посебно као инструмента „за уклањање вештачких препрека развитку нашег књижевног језика у правцу све веће његове јединствености" (НJ н. с. VIII, 3-4, 1956, 84), и долази до потпуног система, онако како је то А. Белић замишљао: система који је део егзактно утврђене синтаксе српскохрватског језика, засноване на савременој језичкој грађи најшире распрострањености и заступљености књижевних, научних, друштвено-политичких и културних стваралаца српскохрватског језичког подручја и који је изложио у делу Савреме ни српскохрватски језик - Граматички системи и књижевнојезичка норма, II, Син такса (Београд 1969, I-VIII + 1-902).

20. (G) Категорија одвојено / састављено писање речи. У програмском чланку из 1923. Александар Белић је само имплицирао ову категорију, са осталим категоријама које подразумева његова констатација правописних задатака: „он [правопис - прим. Ж. Ст.] само показује како ваља написати, изнети коју реч на писму која се у нашем народу или књижевном језику употребљава" (п. о. ПГл XL, 3-5, 1923, 39). Међутим, као што у његовом Пр а в о п и су из 1923. г. и поглавље II (непостојани и покретни самогласници, стр. 10-14), због контактнолингвистичких проблема, поглавље III (књижевни изговори, стр. 15-21), због уједначавања, поглавље XI (употреба $и$ и $\hbar, u$ и $)$, стр. 63-78), због ортоепских, контактнојезичких и проблема уједначења - имају првенствено лингвистички карактер,

\footnotetext{
15 Зборник Филозофског факултета, II, Београд 1952, 17-44.
}

${ }^{16}$ Наш језик н. с. VIII, 3-4, Београд 1956, 71-85. 
тако се и ова категорија, изложена у XVI поглављу Правоп иса из 1923, мора схватити као приказана у истом нивоу. Другим речима, Александар Белић, нормирајући српскохрватски језик, његов писани део - одговара на питање које се тиче одређења речи као језичке јединице.

21. Наиме, А. Белић у своме Правопису, који има своје практичне циљеве, наравно, за речи које ступају у односе погодне за генезу нових језичких јединица тога ранга, дакле за „речи које би се могле писати одвојено и састављено”, ${ }_{17}$ формулише два правила: „(а) Када две или више речи у сталној вези добијају сасвим друго значење него што га имају као засебне речи, онда се пишу заједно", што садржи ортографска решења типа: Сувише је низбрдо према Ја идем низ брдо и сл.: и (б) када се делови сложене речи или не употребљавају самостално или би морали друкчије гласити када би сваки део имао самосталну употребу, онда се ти делови не могу растављено писати", што садржи ортографска решења типа: навлаш, овлаш (према ${ }^{\star}$ влаш), измалена, израна према ${ }^{\star}$ из малена, ${ }^{\star}$ из рана) и сл. ${ }^{18}$ Исти је принцип А. Белић ставио у основу својих правописних решења и много касније, 1950, када додаје и функцију акцента, ${ }^{19}$ ипак истичући „јединство значења или извесно јединство службе (функције) у језику”. А тај принцип задржава, уз појединачне модификације и давање већег значаја акцента као релевантног дела речи (нпр., пред вече према Белићевом предвече и сл.; дистрибутивно по ваздан према Белићевом поваздан итд.), и заједнички Прав опи с MC-MX из 1960. године. ${ }^{20}$

22. Два Белићева правила, у датим оквирима регулисања писане норме језика, представљају лингвистичко одређење речи као језичке јединице, а садрже све битне критеријуме тога одређења, то јест: (а) критеријум значења; (b) критеријум одвојивости / заменљивости / могућности премештања (нпр.: наште, одакле, израна; уврх; поиздаље и сл.); (с) критеријум акустичког идентитета јединице која се сматра једном речи (нпр.: поноћ, обноћ; доба̀рвече̄ из Правописа од 1950), у који се укључује - наравно, и прозодијска страна облика; (d) критеријум кохезије, који је - како се у литератури дефинише - „веза елемената једне речи која онемогућује било какав други елеменат међу њима” (нпр. напоље „изван куће” : “ на/моје/ твоје /отворено.../ поље). Критеријумима, дакле, који се, у овом лингвистичком питању, сада формулишу с обзиром на значај одређивања места речи у језичком систе-

17 А. Белић, Правопис српскохрватског књижевног језика, Београд 1923, 92 и даље.

18 А. Белић, Ibid., 97-98.

19 А. Белић, Правопис српскохрватског књижевног језика, Београд 1950, 24-25 и д.

${ }^{20}$ Правопис МС-MX, 1960, 70-71 и даље до 90. 
му, и посебно у нормирању језика обе његове, и говорне и писане, форме. ${ }^{21}$ У томе правцу, у правцу правописног чиниоца у нормирању језика, била је усмерена, између осталог, и расправа Александра Белића О сложеницама, ${ }^{22}$ лингвистички документована грађом из Рјечника ЈАЗУ, Броз-Ивековића, Ристић-Кангрге, Вуковог Рјечника, Стулића, у периоду изласка Белићевог Правописа српскохрватског књижевног језика из 1950. године, чији је лексикографски део - правописни речник - знатно проширен у односу на раније $\left(1923^{1}, 1930^{2}\right)$, и у којем се дефинисана правила, са критеријумима које садрже, јасно огледају.

23. Као што се може видети, у генези Белићевог рада на правописном кодификовању српскохрватског језика примарну и фундаменталну улогу имала су језичка факта везана за утврђивање комуникативних средстава српскохрватске језичке заједнице као главног оруђа целокупног културноисторијског развоја. Екстралингвистичке чињенице својих настојања дефинисао је и сам Александар Белић, нарочито у погледу оних периода који су захтевали рад на обједињавању граматичарске мисли, што је подразумевало контакте различитих школа, културних центара и општедруштвеног приступа читавом питању. Међутим, и у кратком историјату екстралингвистичког дела правописне генезе, који објашњава наставак Прав оп иса из 1950-1952, његову везу са „споразумним или договореним правописом српскохрватским од 1928/29. године и Боранићевим и Белићевим правописима од 1930. године и каснијим њиховим издањима, одн. са правописним правилима из 1929. године, у Напоменама о српскохраватском правопису 1953. године 23 , па и касније 1958. г., када је рад најновије Правописне комисије већ био у завршним фазама пред појаву новог заједничког Правописа из 1960. године, ${ }^{24}$ дакле - уз екстралингвистичку аргументацију, сама језичка факта задржавала су своје, фундаментално место. „Правопис је” - пише А. Белић - „састављен од појединих правописних система који се морају израдити исто онако као што се израђују и језички системи. Ту ништа не измишља и не одређује граматичар. На основу онога како пишу књижевници и други писци, на основу онога што се јавља у објављеним

${ }^{21}$ B.: Jiři Krámský, The World as a Linguistic Unit, Mouton The Hague - Paris $1969,12,17-40,53-57$.

${ }^{22}$ Наш језик н. с. I, 5-6, Београд 1950, 169-177.

${ }^{23}$ Наш језик н. с. IV, 5-8, Београд, 1953, 130-140 и д. до 148. стр. В. и чланак: Око језика и правописа, Наш језик н. с. IV, 3-4, Београд 1952, 75-82.

${ }_{24}$ В.: А. Белић, Јединство новог правописа, Наш језик н. с. IX, 5-6, Београд $1958,145-147$. 
делима научним, журналистичким, политичким и свима другим - граматичари састављају и језичке и правописне системе, пазећи да се и у једним и у другим огледа језичка и књижевна стварност [...] Правопис има још и својих нарочитих захтева: да буде што простији и што доследнији да би се могло целокупно језичко градиво што лакше савладати." ${ }^{25}$ А овај је чинилац, као констатација сагласности у теоријским научним схв атањима, уз коју се одмах помињу категорије писања великог, одн. малог слова, састављеног, одн. растављеног писања речи, интерпункције и др., истакнут и онда када Александар Белић констатује резултате рада Правописне комисије, која је образована према закључцима заједничког састанка књижевника и лингвиста у Новом Саду 8-10. XII 1954. године. ${ }^{26}$

24. Природно, и у генези Белићевих правописних настојања било је осцилација у решењима, и на њих је он сам скретао пажњу што је и разумљиво када се има на уму чињеница да поред принципа који проистичу из природе језика једне заједнице која је за српскохрватски врло сложена, и који као такви треба да се огледају у правопису, сам правопис чине и конвенционални, договорни елементи, ${ }^{27}$ и то такође врло широког и сложеног спектра захтева. Отуда су лингвисти-кодификатори већ могли констатовати и исправно оквалификовати неке од битних фаза у Белићевом принципу јез ичк их факата управопису, посебно када су у питању односи тога принципа према решењима датим у данашњем правопису. Тако је професор М. Ст ев а н ов ић, и иначе један од два стилизатора последњег Правописа, истакао пионирски посао Александра Белића да „изради један научни правопис, кога код Срба раније није било”, 1923. године, и то управо тако што је констатовао Белићево схватање фоне т ског принципа и његово остваривање везано за категорију облика, другим речима - његово морфофонемско остваривање. „Белић у своме Правопису од 1923. г.” - истиче проф. Стевановић - „није оставио ни једног случаја одступања од асимилације суседних сугласника по звучности колико ни по начину образовања, већ је предложио и мењање слова $\partial$, чак и испред $c$. Он је, и не без разлога, стао на гледиште да од принципа доследне фонетичности правописа не треба отступати у питањима која сама собом не руше други принцип према коме је оправдано избегава-

${ }_{25}$ Напомене о српскохрватском правопису, Наш језик н. с. IV, 5-6, Београд $1953,142-143$.

26 А. Белић, Наш правопис у новој обради, Наш језик н. с. VIII, 3-4, Београд $1956,65-70$.

27 М. Стевановић, За јединствен правопис српскохрватског језика, Наш језик н. с. IV, 5-8, Београд 1953, 149 и д. 
ти промене које унакарађују облик речи, [...] него [да] у писму не треба означавати промене које иза овога настају, јер те промене тек доводе до деформисања речи (тј. од гратски дају грацки, од госпотски дају госпои$\kappa и$, од льтство - љьство), што је скоро свима сметало:" 28 Једновремено, проф. М. Стевановић констатовао је и Белићево схватање екстралингвистичког чиниоца, одн. традиције - са њеним конструктивним чиниоцима, који су услов генерацијског континуитета стандардног језика, или, још тачније, потребе тога језика за таквим континуитетом - и у вези с тим његово прихватање као оправданог „средњег решења”, заснованог на Вуковом поступку, које је резултирало „у (обавезном) остављању непромењеног $\partial$ (као и $ち$ испред $c$ и $\mathcal{u}$, ма у коме се положају у речи они налазили (представа, одшетати, градски, вођство)" и у обавезном једначењу д у $m$ испред безвучних африката (отћушнути, отиепити, натчовек). ${ }^{29}$ То исто, а реч је о категоријама које се стално разматрају по критеријуму спорности у обележавању писмом, констатује се у погледу категорије писања секвенце -иј- у вези са -ски (спахијски, иумадијски), затим у погледу неких случајева састављеног и одвојеног писања речи и израза, у погледу употребе великог, одн. малог слова, дељења речи када се преносе њихови делови (подела у вези са питањима фонетско-фонолошке јединице слога) $)^{30}$ и у још понеком питању, врло често и техничке природе, које улазе у домен ортографије књижевног језика.

25. Као што је Александар Белић могао дефинисати Вуков правопис као конкретан историјски елеменат, што значи и као екстралингв истички потенцијал који је увелико усмеравао каснију кодификацију и књижевног језика српскохрватског (в. т. 1), тако се и систем јез ич ких ч ињен ица који је А. Белић у периоду од 1923. наовамо правописно кодификовао заиста развијао у елементима које је он претпостављао као релевантне и нужне за развитак дате језичке области: у утврђивању језичких система облика, језичких система творбе речи, језичких система синтаксе и лексике. При томе, у свим овим елементима и сам кодификатор - Александар Белић, имао је непрестаног и, што је за формирање књижевнојезичке норме посебно значајно, системског удела. Граматичка мисао тиме се показивала и у своме екстралингвистичком лику, и у својој историјској условљености и одређености.

${ }^{28}$ М. Стевановић, Измене у правопису српскохрватског језика, Наш језик н. с. VIII, 3-5, Београд 1956, 76.

${ }^{29}$ Ibid., 77.

${ }^{30}$ Ibid., 78-85. 